\title{
EFFICIENCY ANALYSIS OF PRIVATE PENSION COMPANIES $(2011-2016)^{1}$
}

\section{Zehra KILINÇ}

Süleyman Demirel Üniversitesi Sosyal Bilimler Enstitüsü Muhasebe ve Finansman Anabilim Dal1, Sorumlu yazar e-mail:zehra88@outlook.com

\section{Fatma MUMCU KÜÇÜKÇAYLI}

Dr. Öğr. Üyesi, Mehmet Akif Ersoy Üniversitesi, Ağlasun MYO, Finans- Bankacılık Sigortacılık Bölümü

\footnotetext{
${ }^{1}$ Efficiency Analysis of Private Pension Companies (2011-2016)-Bu çalışma Mehmet Akif Ersoy Üniversitesi Sosyal Bilimler Enstitüsü, Muhasebe ve Finans Tezli Yüksek Lisans Programında Dr. Öğretim Üyesi Fatma MUMCU KÜÇÜKÇAYLI danışmanlığında yürütülen ve Zehra KILINÇ tarafından yazılan '’Bireysel Emeklilik Şirketlerinde Etkinlik Analizi (2011-2016)', başlıklı tezden üretilmiştir.
} 


\title{
EFFICIENCY ANALYSIS OF PRIVATE PENSION COMPANIES (2011-2016)
}

\begin{abstract}
The individual pension system covers the management of the funds invested by the participants on a voluntarily basis. These funds are important in terms of increasing the country's savings rate as well as increasing the welfare of individuals and the country with the transformation of funds into capital market investments. In recent years, states have increasingly supported the private pension system to provide resources to the investments and increase the saving rates.

The aim of this study is to measure the effectiveness of individual pension companies in Turkey between the years 2011-2016 with data envelopment analysis method. In the analysis phase, while total assets, equity and contribution rates were used as input variables, premium production and investment income were used as output variables. The majority of companies included in the analysis in the first years were below the efficiency limit and in the following years an increase was observed in the efficiency values of the related companies.
\end{abstract}

Keywords: Private Pension System, Data Envelopment Analysis, Efficiency, Productivity, Insurance.

\section{Öz}

Bireysel emeklilik sistemi, katılımcıların gönüllülük esasına göre yatırmış olduğu fonların yönetilmesini kapsar. Yatırılan bu fonlar ülkenin tasarruf oranını arttırırken fonların sermaye piyasasında yatırımlara dönüşmesiyle birlikte bireylerin ve ülkenin refah seviyesini arttırması açısından oldukça önemlidir. Özellikle son yıllarda yapılmış olan yatırımlara kaynak sağlamak, tasarruf oranlarını arttırmak ve istenilen düzeye yükseltmek amacı ile bireysel emeklilik sistemine devlet desteğinin arttığı görülmektedir.

$\mathrm{Bu}$ çalışmanın amacı, Türkiye'deki bireysel emeklilik şirketlerinin 2011-2016 yılları arasındaki etkinliklerini veri zarflama analizi yöntemiyle ölçmektir. Analiz aşamasında Toplam varlıklar, Özsermaye ve katkı payı tutarı girdi değişkeni olarak, prim üretimi ve yatırım gelirleri ise çıktı değişkeni olarak kullanılmıştır. Ele alınan dönem itibari ile ilk yıllarda analize dâhil edilen işletmelerin büyük bir kısmının etkinlik sınırının altında kaldığı ilerleyen yıllarda ise ilgili işletmelerin etkinlik değerlerinde artış olduğu görülmüştür.

Anahtar Kelimeler: Bireysel Emeklilik Sistemi, Veri Zarflama Analizi, Etkinlik, Verimlilik, Sigortacilik.

JEL Kodları: C44, C60, C61, C67, G22 


\section{INTRODUCTION}

People need to plan their future before their retirement to live a life of prosperity. The pension from Social Security Institution may not be enough for a comfortable life. Therefore, the individual pension system is needed and the people who increase the contract allowance are provided with the opportunity to live a life of prosperity in their future lives. With the private pension system implemented in Turkey in 2003 and the reforms implemented in 2013 and 2017, it is aimed to increase savings rates and to create long-term financial resources. The state contribution is $25 \%$ of the amount deposited by the participants and is deposited by the state to the participant's account. The aim of the state contribution is to direct the participants to save money. Also, the private pension system is a trust-based system. It is under constant supervision. Since it is a system with a transparent structure, the participants can easily reach their contributions, returns and the information they want in any time. This is the basis of trust in the foreground. In this way, the confidence of the participants is increased against the system. As of the end of 2017, the total amount of funds provided by the private pension system was around $4 \%$ of the total GDP. This ratio was approximately $51 \%$ in OECD countries. In developing countries such as Turkey, it is around 17\%. From this point of view, the system is not satisfactory despite state contribution.

In response to the answer to the question why the individual pension system is important, in 1980 one retired person meant 3.3 employees. Today, one retired person means 1,95 employees. In 2020, one retired person will mean 1,60 employees. While the amount of the fund amounted to 20 billion Turkish Liras between 2003 and 2013, it was 52,80 billion Turkish Liras with 3,7 million participants (https://www.tsb.org.tr/). The main reason for this increase has been undoubtedly the contribution of our government since 2013.

The purpose of this study, between 2011 and 2016 to measure the effectiveness and efficiency of the 10 private pension companies operating in Turkey with data envelopment analysis. the difference of this study from other studies is that it is the most recent study conducted in recent years. In this respect, the literature on similar subjects is mentioned in the following sections of this study and the Data Envelopment Analysis (DEAP) method is presented. In the following sections, the data used and the analyzes are explained in detail. In the last section, results and recommendations are presented.

\section{LITERATURE}

Data envelopment analysis is widely used in efficiency and productivity measurements in the insurance sector. Especially in recent years, with the spread of the private pension system in our country, the number of studies on this subject has been increasing day by day.

In the study conducted by Tantan et al., 16 life insurance companies' efficiency measurement was done with data envelopment analysis between 1998 and 1999. In this study, capital, labor and commission values were input variables. In terms of output variables, premium values were discussed. As a result of the research, it is determined that only $12 \%$ of the life insurance companies have reached the efficiency limit (Tantan, Yolsal, and Gürbüz, 2000). In another study, Ciftci measured efficiency of 62 insurance companies between 1998 and 2002 with DEA to analyze current situation of the Turkish insurance industry and to reveal problems of life and non-life insurance insurance companies. In the analysis phase, the number of agencies, number of employes, fixed assets and shareholders' equity are considered as input variables. Premium production and profitability ratios are considered as output variables (Çiftçi, 2004). Sezen et al. measured the relative efficiency of 28 insurance companies operating in Turkey between the years 1998 and 2003 with the DEA. In this study, total technical provisions and total paid compensation are considered as output variables while total expenses, equity and total liabilities are considered as input variables. In addition, companies were classified by the number of agencies to determine the differences between efficiency values. As a result of the study, it was seen that only a small part of the insurance companies reached the efficiency limit (Sezen, İnce, and Aren, 2005).

Bulbul and Akhisar have measured the financial efficiency of 30 companies operating in the insurance sector through the DEA. Equity / total assets, equity / technical provisions, liquid assets / assets total, loss ratio, retention ratio are considered as input variables. The technical profit / premium received, financial profit / premium received, balance sheet profit / premium received, technical profit / 
balance sheet profit rates were used as the output variables. As a result of the analysis, it was determined that most of the companies in the industry could not reach the efficiency limit (Bülbül and Akhisar, 2005). In another study, Kaplan and Çelik measured the efficiency levels of companies operating in the Turkish insurance sector through the DEA. Then, through the tobit regression model, they determined the factors determining the efficiency levels of companies. It was determined that most of the companies included in the study could not use their resources effectively (Kaplan and Çelik, 2007).

Looking at other studies conducted in the Turkish insurance industry through data envelopment analysis, Altan measured, the financial performance of 25 companies operating in the non-life insurance sector between 2005-2007 (Altan, 2010), Özcan measured both operational and financial performances of non-life insurance companies (Özcan, 2011), Karakaya et al, measured the efficiency of 14 private pension companies in 2011 (Karakaya et al, 2014), Özbek measured the financial and operational efficiencies of non-life insurance companies between 2010 and 2014 (Özbek, 2015), Ayhan measured the efficiency of life and non-life insurance companies operating in European Union and Turkey for the years between 2010 and 2015 with DEA (Ayhan, 2017). Moreover, Özüdoğru measured the financial performance of 7 insurance companies traded on the BIST between the years 2014 and 2016 (Özüdoğru, 2017), Özaktaş measured the efficiency of non-life insurance companies for the years between 2002 and 2015 with DEA in terms of both insurance and portfolio activities (Ozaktaş and Davarcioğlu, 2017).

\section{DATA ENVELOPMENT ANALYSIS METHOD}

Data envelopment analysis, which is an improved method for eliminating the obstacles in the analysis of efficiency, was used in the first place to measure the efficiency of non-profit organizations. In later periods, it was started to be used in industries working with profit (Yolalan, 1993: 27). However, in today's literature, data envelopment analysis is used in many industries such as banks, hotels, insurance, hospitals and factories. In the application phase of the analysis, the related organizations are compared with the other organizations in the industry where they operate and their relative efficiency is tried to be determined (Tetik, 2003: 222).

In the literature on data envelopment analysis, different forms of identification are seen. Some of these are those:

Data envelopment analysis is a type of analysis that uses a large number of inputs and outputs to evaluate the relative efficiency of each decision element (Lang et al, 1995: 473).

Data envelopment analysis is the best observation value obtained as a result of comparing homogeneous production factors among themselves by considering the efficiency limit and evaluating the other observations according to this best observation (Seyrek and Ata, 2010: 70).

Data envelopment analysis is a non-parametric method which is compatible with the production economy, which offers the ability to measure the relative total factor effectiveness in cases where there are multiple inputs and outputs of different units and these inputs and outputs cannot be evaluated in a common criterion (Güran and Cingi, 2002: 64).

Data envelopment analysis is a mathematical programming based analysis that can convert multiple inputs and outputs into a quantitative efficiency criterion. The most important feature of the analysis is to evaluate the effectiveness of decision elements with similar characteristics during production. It is expected that the decision-making units in the analysis function the same for similar purposes, operate in the same market conditions, and the factors explaining the efficiency of all the elements within the group are very close to each other except for the differences in their density and size (Karsak and İşcan, 2000: 3).

\subsection{CCR Model}

The CCR model, which was first formed by Charnes, Cooper and Rhodes in 1978, is based on the assumption of constant return according to the scale. The model name is derived from the initials letters of people' names who formed CCR model (Lorcu, 2008: 71).

The CCR model is a suitable model for companies to measure efficiency when they operate at optimum levels (Tone, 2001: 32). However, the CCR model evaluates and measures the efficiency of 
decision-making elements, both separately and collectively, based on the scale's constant return assumption (Weng et al, 2009: 41).

The mathematical representation of the CCR model for input is as follows (Özçelik et al, 2017: 46-47).

$$
\begin{aligned}
& E_{k}=\operatorname{Mina}-\varepsilon\left(\sum_{i=1}^{m} S_{i}-\right)-\varepsilon\left(\sum_{r=1}^{p} S_{r}^{+}\right) \\
& \left(\sum_{j=1}^{n} X_{i j} \lambda_{j}+S_{i}^{-}-a X_{i k}\right)=0 \\
& \left(\sum_{j=1}^{n} Y_{r j} \lambda_{j}+S_{i}^{+}-Y_{r k}\right)=0 \\
& \lambda_{j} \geq 0 \\
& S_{i}^{+} \geq 0 \\
& j=1, \ldots \ldots, n \\
& 1=1, \ldots \ldots, p \\
& i=1, \ldots \ldots, m
\end{aligned}
$$

Above;

$\alpha$ : The contraction coefficient which determines how much the input of the " $k$ " decision units decrase.

\subsection{BCC Model}

The BCC model, which was formed by Banker, Charnes and Cooper for the first time in 1984, is based on the assumption of variable return according to the scale. The model name is derived from the initials letters of people' names who formed the model (BCC). BCC models measure the efficiency of decision-making units that produce on a certain scale different from the CCR models based on the assumption of variable return (İşbilen Yücel, 2010: 71).

Data envelopment analysis was developed based on the constant return assumption of scale in the first period of use. According to the constant return assumption of scale, the rate of increase in the amount of input and the rate of increase in the output amount is the same. The total efficacy results obtained by the CCR model include both the efficiency of the scale and the technic. In the following years, the BCC model was developed based on the assumption that the convexity constraint could which enables measuring the efficiencies of scale and technic separetely. Through the BCC model, whether or not the decision units are placed on the efficiency frontier, in other words, whether the decision-making units reach the technical efficiency or not, it also shows the direction of return according to the scale. In addition, when the amount of input in the production stage is increased, if the rate of increase in the output amount is more than the increase in the amount of input, the "increasing returns to the scale", if the rate of increase in output is less than the increase in the amount of input, there is a "decreasing returns to the scale". In other words, if the decision-making units increase their productivity when they increase their scales by maintaining their technical efficiencies, in this case, it is possible to mention the increasing returns to the scale, if they increase their productivity when they decrease their scales by maintaining their technical efficiencies, then decreasing returns to the scale is mentioned in this case (Kazançoğlu, 2010: 141).

The mathematical method of the BCC model for input is as follows (Banker et al 2004: 346-347):

$$
\mathrm{E}_{\mathrm{k}}=\operatorname{Min} \alpha-\varepsilon\left(\sum_{\mathrm{i}=1}^{\mathrm{m}} \mathrm{S}_{\mathrm{i}}^{-}\right)-\varepsilon\left(\sum_{\mathrm{r}=1}^{\mathrm{p}} \mathrm{S}_{\mathrm{r}}^{+}\right)
$$




$$
\begin{aligned}
& \left(\sum_{j=1}^{n} X_{i j} \lambda_{j}+S_{i}^{-}-a X_{i k}\right)=0 \\
& \left(\sum_{j=1}^{n} Y_{r j} \lambda_{j}+S_{i}^{+}-Y_{r k}\right)=0 \\
& \sum_{j=1}^{n} \lambda_{j}=1
\end{aligned}
$$

Above;

$\alpha$ : The contraction coefficient which determines how much the input of the " $k$ " decision units decrease.

\section{IMPLEMENTATION}

Data envelopment analysis begins with the determination of decision-making units. In this context, first of all, all companies are continuous operating in the insurance sector in Turkey between the years 2011-2016. The second stage is to select the input and output set. In this respect, the first input variable of the study is total assets which were used studies of (Köseoğlu, 2009) and (Karakaya et al, 2014). The second input variable is the equity which was used in the studies of (Salimi Altan, 2010) and (Ertuğrul, 2010). The last input variable is the contribution amount which was used in the studies of (Teresa and Garcia, 2010) and (Kabak, 2010). The output variables are the premium production which was used in the studies of (Sezen et al, 2005) and (Çetintaş and Biçen, 2011); and the investment income which was used in the study carried out by (Kızılgeçit, 2014). Bu çalışmada Türkiye'de faaliyet gösteren 2012-2016 yılındaki emeklilik şirketlerininden kes Data related to private pension companies was obtained from reports generated about the insurance and pension activities in Turkey. These reports were reached from the Turkish Republic Undersecretaries of the Treasury website.

The third step of data envelopment analysis is to measure efficiency. In this respect, the efficiency measurement of the individual pension companies was carried out with input-oriented CCR and BCC models of the data envelopment analysis. The reason why the input-oriented model is selected is the assumption that the related companies may be more effective on input variables than the input variables.

The fourth stage of the analysis is the creation of scale effectiveness and reference set. The effectiveness of the scale is determined by dividing the efficiency value of the CCR model by the efficiency value of the BCC model. The reference set shows the companies that should be taken as samples by inefficient companies. DEAP 2.1 software program was used in the analysis phase. As a result of the efficiency measurement carried out by data envelopment analysis, the efficiency values and reference set of the related companies for the years 2011-2016 are given in the tables below.

Table 1. Input-Oriented CCR, BCC, Scale Efficiency Values With Reference Cluster of Private Pension Companies (2011)

\begin{tabular}{|l|c|c|c|l|}
\hline Companies & CCR Model & BCC Model & Scale Efficiency & Reference Cluster \\
\hline Aegon P. & 0,191 & 1,000 & 0,191 & Ziraat \\
\hline Allianz P. & 0,187 & 0,390 & 0,479 & Ziraat \\
\hline Anadolu P. & 0,231 & 0,828 & 0,280 & Ziraat \\
\hline Avivasa P. & 0,383 & 0,482 & 0,795 & Ziraat \\
\hline BNP Paribas & 0,061 & 0,061 & 0,993 & Ziraat \\
\hline Garanti P. & 0,229 & 0,770 & 0,298 & Ziraat \\
\hline Groupama P. & 0,268 & 0,396 & 0,679 & Ziraat \\
\hline Metlife P. & 0,434 & 1,000 & 0,434 & Ziraat \\
\hline Vakif P. & 0,290 & 0,302 & 0,963 & Ziraat \\
\hline
\end{tabular}




\begin{tabular}{|l|c|c|c|l|}
\hline Ziraat P. & 1,000 & 1,000 & 1,000 & Ziraat \\
\hline Mean & $\mathbf{0 , 3 2 8}$ & $\mathbf{0 , 6 2 3}$ & $\mathbf{0 . 6 1 1}$ & \\
\hline Number of Efficiency Firms & 1 & 3 & 1 & \\
\hline
\end{tabular}

As a result of the efficiency measurement conducted with DEA in 2011, it can be seen that only the Ziraat pension company was efficient according to the input-oriented CCR model and the Aegon, Metlife and Ziraat pension companies were efficient according to the BCC model. The reason for the high number of efficient companies in the BCC model is that while in the CCR model total efficiency is measured, in the BCC model local efficiency is measured. In other words, the efficiency limit of the BCC model is lower than the efficiency limit of the CCR model. It has been determined that Ziraat pension company which is efficient in the both models is taken as an example by inefficient companies.

Table 2. Input-Oriented CCR, BCC, Scale Efficiency Values With Reference Cluster of Private Pension Companies (2012)

\begin{tabular}{|l|c|c|c|l|}
\hline Companies & CCR Model & BCC Model & Scale Efficiency & Reference Cluster \\
\hline Aegon P. & 0,336 & 1,000 & 0,336 & Ziraat \\
\hline Allianz P. & 0,313 & 1,000 & 0,313 & Ziraat \\
\hline Anadolu P. & 0,185 & 0,641 & 0,288 & Ziraat \\
\hline Avivasa P. & 0,300 & 0,335 & 0,897 & Ziraat \\
\hline BNP Paribas & 0,100 & 0,103 & 0,973 & Ziraat \\
\hline Garanti P. & 0,137 & 0,511 & 0,268 & Ziraat \\
\hline Groupama P. & 0,210 & 0,292 & 0,719 & Ziraat \\
\hline Metlife P. & 0,388 & 0,393 & 0,987 & Ziraat \\
\hline Vakıf P. & 0,340 & 0,359 & 0,946 & Ziraat \\
\hline Ziraat P. & 1,000 & 1,000 & 1,000 & Ziraat \\
\hline Mean & $\mathbf{0 , 3 3 1}$ & $\mathbf{0 , 5 6 3}$ & $\mathbf{0 , 6 7 3}$ & \\
\hline Number of Efficiency Firms & & & & 1 \\
\hline
\end{tabular}

In 2012, according to the efficiency measurement conducted with DEA's input-oriented CCRmodel, only Ziraat pension company was efficient. According to the BCC model, Aegon, Alianz and Ziraat pension companies were efficient. As in 2011, the companies that are below the efficiency limit in 2012 should take the example of Ziraat Pension Company to be efficient.

Tablo 3. Input-Oriented CCR, BCC, Scale Efficiency Values With Reference Cluster of Private Pension Companies (2013)

\begin{tabular}{|l|c|c|c|c|}
\hline \multicolumn{1}{|c|}{ Companies } & CCR Model & BCC Model & Scale Efficiency & Reference Cluster \\
\hline Aegon P. & 0,689 & 1,000 & 0,689 & Ziraat \\
\hline Allianz P. & 0,307 & 0,382 & 0,804 & Ziraat \\
\hline Anadolu P. & 0,266 & 0,629 & 0,423 & Ziraat \\
\hline Avivasa P. & 0,574 & 0,613 & 0,936 & Ziraat \\
\hline BNP Paribas & 0,126 & 0,131 & 0,956 & Ziraat \\
\hline Garanti P. & 0,179 & 0,560 & 0,320 & Ziraat \\
\hline Groupama P. & 0,297 & 0,319 & 0,931 & Ziraat \\
\hline Metlife P. & 0,415 & 0,436 & 0,951 & Ziraat \\
\hline Vakıf P. & 0,493 & 0,520 & 0,948 & 1,000 \\
\hline Ziraat P. & 1,000 & 1,000 & $\mathbf{0 , 7 9 6}$ & \\
\hline Mean & $\mathbf{0 , 4 3 5}$ & $\mathbf{0 , 5 5 9}$ & & \\
\hline
\end{tabular}


\begin{tabular}{|l|l|l|l|l|}
\hline Number of Efficiency Firms & 1 & 2 & 1 & \\
\hline
\end{tabular}

As a result of the efficiency measurement conducted with the input-oriented CCR model of the data envelopment analysis in 2013, all companies other than Ziraat were below the efficiency limit. In theBCC model, Ziraat and Aegon companies were efficient. Ziraat has been the company that inefficient companies take as a model.

Table 4. Input-Oriented CCR, BCC, Scale Efficiency Values With Reference Cluster of Private Pension Companies (2014)

\begin{tabular}{|c|c|c|c|c|}
\hline Companies & CCR Model & BCC Model & Scale Efficiency & Reference Cluster \\
\hline Aegon P. & 1,000 & 1,000 & 1,000 & Aegon \\
\hline Allianz P. & 0,911 & 1,000 & 0,911 & Aegon, Avivasa, Ziraat \\
\hline Anadolu P. & 0,490 & 0,592 & 0,827 & Aegon, Avivasa, Ziraat \\
\hline Avivasa P. & 1,000 & 1,000 & 1,000 & Avivasa \\
\hline BNP Paribas & 0,290 & 0,352 & 0,823 & Aegon, Ziraat \\
\hline Garanti P. & 0,425 & 0,669 & 0,635 & Avıvasa, Ziraat \\
\hline Groupama P. & 0,601 & 0,642 & 0,936 & Aegon, Avıvasa Ziraat \\
\hline Metlife P. & 0,537 & 0,537 & 0,999 & Aegon, Ziraat \\
\hline Vakıf P. & 0,988 & 1,000 & 0,988 & Avıvasa, Ziraat \\
\hline Ziraat P. & 1,000 & 1,000 & 1,000 & Ziraat \\
\hline Mean & 0,724 & $\mathbf{0 , 7 7 9}$ & 0,912 & \\
\hline Number of Efficiency Firms & 3 & 5 & 3 & \\
\hline
\end{tabular}

In the efficiency measurement which is done with DEA in 2014, according to input-oriented CCR model, Aegon, Avivasa and Ziraat pension companies reached the efficiency limit while Aegon, Ziraat, Allianz, Avıvasa and Vakıf pension companies reached the efficiency limit according to the inputoriented BCC model. It is seen that the companies that are efficient in both models are taken as reference by the companies that are not efficient.

Table 5. Input-Oriented CCR, BCC, Scale Efficiency Values With Reference Cluster of Private Pension Companies (2015)

\begin{tabular}{|c|c|c|c|c|}
\hline Companies & CCR Model & BCC Model & Scale Efficiency & Reference Cluster \\
\hline Aegon P & 1,000 & 1,000 & 1,000 & Aegon \\
\hline Allianz P & 1,000 & 1,000 & 1,000 & Allianz \\
\hline Anadolu P & 0,589 & 1,000 & 0,589 & Aegon, Allianz \\
\hline Avivasa $\mathrm{P}$ & 1,000 & 1,000 & 1,000 & Avıvasa \\
\hline BNP Paribas & 0,260 & 0,310 & 0,839 & Aegon, Avivasa, Ziraat \\
\hline Garanti P. & 0,272 & 0,945 & 0,287 & Avıvasa, Ziraat \\
\hline Groupama P. & 0,405 & 0,419 & 0,968 & Aegon, Ziraat \\
\hline Metlife P. & 0,633 & 0,716 & 0,884 & Aegon, Avıvasa, Ziraat \\
\hline Vakıf P. & 0,557 & 0,562 & 0,991 & Aegon, Ziraat \\
\hline Ziraat $\mathrm{P}$. & 1,000 & 1,000 & 1,000 & Ziraat \\
\hline Mean & 0,671 & 0,795 & 0,856 & \\
\hline Number of Efficiency Firms & 4 & 6 & 4 & \\
\hline
\end{tabular}

In the efficiency measurement which is done with DEA in 2015, according to input-oriented CCR model, Aegon, Allianz, Avıvasa and Ziraat pension companies were efficient. According to input- 
oriented BCC model, besides these companies Anadolu pension company was efficient. In 2015, the number of companies that were taken as a reference increased.

Table 6. Input-Oriented CCR, BCC, Scale Efficiency Values With Reference Cluster of Private Pension Companies (2016)

\begin{tabular}{|l|c|c|c|l|}
\hline \multicolumn{1}{|c|}{ Companies } & CCR Model & BCC Model & Scale Efficiency & \multicolumn{1}{|l|}{ Reference Cluster } \\
\hline Aegon P. & 1,000 & 1,000 & 1,000 & Aegon \\
\hline Allianz P. & 0,747 & 1,000 & 0,747 & Ziraat \\
\hline Anadolu P. & 1,000 & 1,000 & 1,000 & Anadolu \\
\hline Avivasa P. & 1,000 & 1,000 & 1,000 & Av1vasa \\
\hline BNP Paribas & 1,000 & 1,000 & 1,000 & BNP \\
\hline Garanti P. & 1,000 & 1,000 & 0,000 & Garanti \\
\hline Groupama P. & 0,417 & 0,687 & 0,607 & Aegon, Ziraat \\
\hline Metlife P & 0,665 & 0,690 & 0,964 & Aegon, BNP, Ziraat \\
\hline Vakif P. & 0,574 & 0,589 & 0,974 & Ziraat \\
\hline Ziraat P. & 1,000 & 1,000 & 1,000 & Ziraat \\
\cline { 1 - 3 } Mean & $\mathbf{0 , 8 4 0}$ & $\mathbf{0 , 8 9 7}$ & $\mathbf{0 , 9 2 9}$ & \\
\cline { 1 - 3 } Number of Efficiency Firms & 6 & 7 & 6 & \\
\hline
\end{tabular}

In 2016, efficiency measurement according to both the input-oriented CCR model and the inputoriented BCC model showed an increase in the number of companies which are efficient. Likewise, there was an increase in the number of companies that are efficient in terms of scale efficiency.

One of the advantages of data envelopment analysis is to show how to increase or decrease the input and output values so that inefficient decision-making units can be efficient. Table 7 shows how the inefficient individual pension companies should reduce the target input variables because the CCR model for input is used in the analysis. In terms of space saving and exemplary data, only 2016 data were discussed.

Tablo 1. Actual and Provision Values According to Input Oriented DEA for Inactive Individual Pension Companies (2016)

\begin{tabular}{|c|c|c|l|c|l|l|}
\hline \multirow{2}{*}{ FIRMS } & \multicolumn{2}{|c|}{ CAPITAL (TL) } & \multicolumn{2}{l|}{ CONTRIBUTION MARGIN (TL) } & \multicolumn{2}{c|}{ TOTAL ASSETS (TL) } \\
\cline { 2 - 7 } & ACTUAL & PROVISION & ACTUAL & PROVISION & ACTUAL & PROVISION \\
\hline ALLIANZ & 79.496 .000 & 68.796 .125 & 1.267 .045 .417 & 1.040 .118 .029 & 2.263 .273 .000 & 1.854 .155 .698 \\
& & & & & & \\
\hline GROUPAMA & 122.402 .000 & 108.458 .103 & 651.918 .559 & 548.869 .351 & 1.195 .878 .000 & 951.563 .268 \\
\hline METLIFE & 544.973 .000 & 413.269 .132 & 728.305 .785 & 610.237 .487 & 1.949 .772 .000 & 1.468 .963 .147 \\
& & & & & & \\
\hline VAKIF & 200.731 .000 & 147.597 .321 & 2.864 .821 .471 & 2.101 .982 .555 & 4.227 .609 .000 & 3.508 .291 .165 \\
\hline
\end{tabular}

\section{CONCLUSION}

The private pension system is a system that people use as an investment tool for the future. Employees are required to make investments in order to sustain a life of prosperity during retirement. For this reason, individuals have been directed to individual pension as well as the insurance institution. Participation in the private pension system, which became operational in 2003, is increasing day by day. Today, the system is still active effectively. As of 2013, the system has become more attractive with the state support of $25 \%$ contribution. The system has gained a better momentum with this support. 
Private pension companies' efficiency measurement between 2011 and 2016 was done with data envelopment analysis which is an input-oriented CCR and BCC model. It was seen that the number of efficient companies was few between 2011 and 2014. However, it increased between 2015 and 2016. It can be said that this is due to the increasing importance given to the private pension system in Turkey in recent years.

In the efficiency measurement, it was found that Ziraat was efficient throughout both periods in both models. At the same time, it is seen that Ziraat is an example of a company that is below the productivity limit. In addition, it has been determined that the companies that are continuously referenced are efficient in both models. The reason why Ziraat is consistently effective is that it is a company with public capital. It was determined that Aegon was the most efficient company except Ziraat. Groupama is the worst performing company between 2011 and 2016, which is below the efficiency limit in both models. Vakıf is continuously below the limit of efficiency according to the input-oriented CCR model. Only in 2014 it was found to be efficient according to the input-oriented BCC model. Metlife was only efficient in 2011 according to the input-oriented BCC. In other years, it was below the efficiency limit. It is determined that Garanti and BNP Paribas companies are efficient only in both models in 2016 and not in other years. Anadolu was efficient in 2016 in both models. However, it was efficient in 2015 according to BCC model. In other years, it was found that it remained below the efficiency limit. Avivasa was found to be efficient between 2014 and 2016 in both models. However, it was inefficient between 2011 and 2013 in both models. It is determined that Allianz has a fluctuating course in terms of efficiency.

It is thought that this study, which measures the efficiency of private pension companies, will guide the managers of the relevant companies. Moreover, it is thought that the data obtained will be analyzed and will enable managers to develop new strategies to increase financial and operational efficiency.

The choice of input-output variables in data envelopment analysis greatly affects the results of the efficiency measurement. Therefore, the efficiency of companies may vary depending on input and output variables. In this context, increasing the number of companies involved in the analysis, more detailed results can be obtained by increasing the number of years sampled and creating an input-output from the data that clearly shows the financial and operational situation.

\section{REFERENCES}

Ayhan, C., (2017), Türkiye'deki Sigortacılık Sektörünün Etkinlik Analizi Ve AB Ülkeleriyle Karşılaştırılması, Pamukkale Üniversitesi, Sosyal Bilimler Enstitüsü. (Yüksek Lisans Tezi), Denizli.

Banker, R., Cooper, W. W., Seiford, L. M., Thrall, R. M., and Zhu, J., (2004), "Returns To Scale İn Different Dea Models", European Journal of Operational Research, C. 154, S. 2, ss. 345-362.

Bülbül, S. ve Akhisar, İ., (2005), Türk Sigorta Şirketlerinin Etkinliğinin Veri Zarflama Analizi İle Araştırılması, VII Ulusal Ekonometri ve İstatistik Sempozyumu (s. 1-12). İstanbul: İstanbul Üniversitesi.

Çetintaş, H. ve Biçen, F., (2011), "Türkiye'de Sigorta Sektörünün Etkinlik Analizi", Tisk Akademi, ss. 124-154.

Çiftçi, H., (2004), "Türk Sigorta Sektörünün Sorunları: Dea Analizi İle Türk Sigorta Şirketlerinin Etkinlik Düzeylerinin Belirlenmesi", Çukurova Üniversitesi Sosyal Bilimler Enstitüsü Dergisi, C. 13, S. 1, ss. 1-29.

Ertuğrul, E., (2010), Bireysel Emeklilik Sektörü İçin Etkinlik Analizi: Türkiye Örneği (2004-2005), Gazi Üniversitesi, Sosyal Bilimler Enstitüsü. (Yüksek Lisans Tezi), Ankara.

Güran, M. C. ve Cingi, S., (2002), "Devletin Ekonomik Müdahalelerinin Etkinliği", Akdeniz İ.İ.B.F. Dergisi, C. 3, ss. 56-59. 
İşbilen Yücel, L., (2010), Portföy Etkinliğinin Veri Zarflama Analizi İle Ölçülmesi Ve Portföy Etkinleştirilmesine Yönelik Bir Uygulama, İstanbul Üniversitesi, Sosyal Bilimler Enstitüsü. (Doktora Tezi), İstanbul.

Kaplan, M. ve Çelik , T., (2007), "Türk Sigortacılık Sektöründe Etkinlik Ve Etkinliği Belirleyen Faktörler", İktisad İşletme ve Finans, C. 22, S. 253, ss. 97-114.

Karakaya, A., Kurtaran, A. ve Dağl1, H., (2014), "Bireysel Emeklilik Şirketlerinin Veri Zarflama Analizi İle Etkinlik Ölçümü: Türkiye Örneği", Yönetim ve Ekonomi Araştırmaları Dergisi, C. 12, S. 22, ss. 1-23.

Karsak, E. ve İşcan, F, (2000), "Çimento Sektöründe Göreli Faaliyet Performanslarının Ağırlık Kısıtlamaları Ve Çapraz Etkinlik Kullanılarak Veri Zarflama Analizi İle", Endüstri Mühendisliği Dergisi, C. 11, S. 3, ss. 2-10.

Kazançoğlu, F. Ş., (2010), Türkiye Enerji Sektöründe Toplam Faktör Verimliliği Ve Uluslararası Konum Analizi, Gazi Üniversitesi, Ankara.

Kisakesen, V., (2010), The Efficiency Analysis Of The Private Pension Firms In Turkey, Marmara Üniversitesi, Sosyal Bilimler Enstitüsü. (Yüksek Lisans Tezi) İstanbul.

Kızılgeçit,, Z., (2014), Bireysel Emeklilik Sistemi Ve Bireysel Emeklilik Sistemindeki Sigorta Şirketlerinde Fon Yönetimi, Atatürk Üniversitesi, Sosyal Bilimler Enstitüsü. (Yüksek Lisans Tezi), Erzurum.

Köseoğlu, A., (2009), Veri Zarflama Analizi İle Türkiye'deki Bireysel Emeklilik Şirketlerinin Etkinliğinin İncelenmesi, Marmara Üniversitesi, Bankacılık ve Sigortacılık Enstitüsü. (Yüksek Lisans Tezi), İstanbul.

Lang, P., Yolalan, R. and Kettani, O., (1995), "Controlled Envelopment By Face Extension", Journal of the Operational Research Society, C. 46, S. 4, ss. 473-491.

Lorcu, F., (2008), Veri Zarflama Analizi (Dea) İle Türkiye Ve Avrupa Birliği Ülkelerinin Sağlık Alanındaki Etkinliklerinin Değerlendirilmesi, İstanbul Üniversitesi, Sosyal Bilimler Enstitüsü. (Doktora Tezi), İstanbul.

Özaktaş Davarcıoğlu, F., (2017), "Hayat Dışı Sigorta Sektöründe Etkinlik Analizi: Türkiye Uygulaması (2002-2015)", Ç.Ü. Sosyal Bilimler Enstitüsü Dergisi, C. 26, S. 2, ss. 30-44.

Özbek, A., (2015), "Analysis Of Private Pension Companies In Turkey By Eatwos", European Journal of Business and Management, C. 7, S. 26, ss. 33-44.

Özcan, A. İ., (2011), "Türkiye'de Hayat Dışı Sigorta Sektörünün 2002-2009 Dönemi İtibariyle Etkinlik Analizi", Celal Bayar Üniversitesi Sosyal Bilimler Dergisi, C. 9, S. 1, ss. 61-78.

Özçelik, H. ve Kandemir, B., (2017), "Veri Zarflama Analizi Ve İmalat Sektöründe Bir Uygulama", Süleyman Demirel Üniversitesi İktisadi ve İdari Bilimler Fakültesi Dergisi, C. 22, S. 1, ss. 4353.

Özüdoğru, H., (2017), "Türkiye'de Sigorta Şirketlerinde Veri Zarflama Yöntemi İle Etkinlik Ölçme Üzerine Bir Araştırma", Üçüncü Sektör Sosyal Ekonomi, C. 52, S. 3, ss. 82-96.

Salimi Altan, M., (2010), "Türk Sigortacılık Sektöründe Etkinlik: Veri Zarflama Analizi Yöntemi İle Bir Uygulama", Gazi Üniversitesi İktisadi ve İdari Bilimler Fakültesi Dergisi, C. 12, S. 1, ss. 185-204.

Seyrek, İ. H. ve Ata, A., (2010), "Veri Zarflama Analizi Ve Veri Madenciliği İle Mevduat Bankalarında Etkinlik Ölçümü", BDDK Bankacılık ve Finansal Piyasalar, C. 4, S. 2, ss. 67-84.

Sezen, B., İnce, H. ve Aren, S., (2005), "Türkiye'deki Hayat Dışı Sigorta Şirketlerinn Veri Zarflama Analizi Tekniği İle Göreli Etkinlik Değerlemesi", İkitisad ve İşletme Dergisi, C. 20, S. 236, ss. 87-95. 
Tantan, S., Yolsal, H. and Gürbüz, A. O., (2000), "Efficiencey In Turkish Life Insurance Industry( Using Dea Approach)", European Financial Management Association Conference. Atina: Social Science Research Network.

Teresa, M. and Garcia, M., (2010), "Efficiency Evaluation Of The Portuguese Pension Funds Management Companies", Journal Of International Financial Markets Intitutions\& Money, C. 20, S. 3, ss. 259-266.

Tetik, S., (2003), "İşletme Performansını Belirlemede Veri Zarflama Analizi". Celal Bayar Üniversitesi İ.İ.B.F. Dergisi, C. 10, S. 2, ss. 221-229.

Tone, K., (2001), "A Slacks- Based Measure Of Efficiency In Data Envelopment Analysis", European Journal of Operational Research, C. 130, S. 3, ss. 498-509.

Weng, S. J., Wu, T., Blackhurst, J. and Mackulak, G., (2009), "An Extended DEA Model For Hospital Performance Evaluation And İmprovement", Health Service Outcomes Research Method, C. 9, S. 1, ss. 39-53.

Yolalan, R., (1993), İşletmelerarası Göreli Etkinlik Ölçümü, Milli Prodüktivite Merkezi Yayınları, Ankara. 